\title{
Cutaneous Melanoma pN1 TNM Finding v6
}

National Cancer Institute

\section{Source}

National Cancer Institute. Cutaneous Melanoma pN1 TNM Finding v6. NCI Thesaurus. Code 448856.

Cutaneous melanoma with involvement of one lymph node. (from AJCC 6th Ed.) 